\title{
ASSESSMENT OF CROSS COMPATIBILITY OF PEAR (Pyrus communis L.) CULTIVARS ON THE BASIS OF POLLEN TUBE OBSERVATIONS AND ANALYSIS OF THE S-RNASE GENE
}

\author{
Wojciech Antkowiak ${ }^{1}$, Andrzej Wojciechowski², \\ Lukasz Wolko ${ }^{3}$, Grzegorz Łysiak ${ }^{4}$ \\ ${ }^{1}$ Department of Botany, ${ }^{2}$ Department of Genetics and Plant Breeding, \\ ${ }^{3}$ Department of Biochemistry and Biotechnology, ${ }^{4}$ Department of Pomology \\ Poznań University of Life Sciences, Wojska Polskiego 28, 60-637 Poznań, Poland \\ e-mail: ajwoj@up.poznan.pl
}

Received: 10.03.2012

\begin{abstract}
Diallel crosses of $P$. communis cultivars: 'Amfora', 'Radana', 'Red Williams', 'Carola', 'Conference', and 'Dicolor', were conducted under orchard and laboratory conditions at temperatures of $20^{\circ} \mathrm{C}$ and $28^{\circ} \mathrm{C}$. Based on pollen tube observations and after the determination of the $\mathrm{S}$ genotypes, the usefulness of these pear cultivars as cross pollinators was evaluated as good and very good.
\end{abstract}

Key words: Pyrus communis, incompatibility, pollen tubes, pollinator

\section{INTRODUCTION}

Pyrus communis L. is one of two species of pear trees grown for food purposes. Production of pears throughout the European Union in 2009 amounted to 2.52 million tons (http://www.fresh-market.pl/katalog produktow/owoce/grusze/produkcja;1883888737). For comparison, in 20082.43 million tons were harvested, while in 20072.71 million tons. In 2008 most fruits were collected in Italy (811 thousand tons) and Spain (558 thousand tons); in Poland it was 80 thousand tons in 2009, 52 thousand tons in 2008, and 62 thousand tons in 2007. According to Prognosfruit, in the European Union the production of this species in 2009 was based on a few cultivars, such as: 'Conference' (856 thousand tons), 'Abate Fetel' (277 thousand tons), 'William BC' (296 thousand tons) and Rocha (180 thousand tons) (World Apple and Pear Association Report - http://www.wapa-association.org/ docs/2010/Facts_and_Figures/EU_Commission_market_report_on_pears.pdf).
Most species of fruit trees, including pear (Py$r u s)$, is characterized by gametophytic self-incompatibility. The essence of self-incompatibility system is that the pistil recognizes the pollen with which it was pollinated. If the pollen comes from a genetically distinct individual, it is possible to form a pollen tube and transfer the male genetic material to the embryo sac. If the pollen carries the same genetic information as the pistil, the development of the pollen tube is inhibited. The gametophytic incompatibility system of pollen grain germination and growth of the pollen tube are controlled by a series of multiple alleles ( $\mathrm{S}$ - allele).

According to McClure et al. (1989), the $\mathrm{S}$ locus includes, among other genes, the gene encoding RNase, which is expressed within the stigma before pollination. The action of S-RNase allotype affects the recognition and blocking fertilization of an egg cell by a male gamete from incompatible pollen. Hence, a clear understanding of the problem of incompatibility is very helpful for orchard practice.

From the point of view of orchard practice, cross-pollination is necessary to obtain high yields as well as properly shaped fruits. During the establishment of an orchard, it is very important to select appropriately pollinators from diploid cultivars blooming in the same period. In the case of new cultivars, there are often no completely reliable sources that would provide reliable information about pollinators.

Therefore, the aim of this study was to evaluate the usefulness of new and traditionally home-grown pear ( $P$. communis) cultivars ('Amfora', 'Radana', 'Red Williams', 'Carola', 'Conference' and 'Dicolor') as a good pollinator. 


\section{MATERIALS AND METHODS}

\section{Plant material}

Adult trees of $P$. communis cultivars 'Amfora', 'Radana', 'Red Williams', 'Carola', 'Conference' and 'Dicolor' were grown at the Przybroda orchard of the Poznan University of Lifer Sciences, Poland.

Pollination and pollen tube growth observations

The pollen of particular pollinators was placed on stigmas 1-2 days after emasculation, which was done at the flower bud stage. The mode of pollination consisted of intracultivar self- and cross-pollination and intercultivar diallel cross-pollination, as it is presented in Table 1. The pollination was done in three different environmental conditions, i.e. under orchard (designated as treatment 1), glasshouse (treatment 2), and laboratory conditions (treatment 3). Pollination under the glasshouse (at a temperature of $20^{\circ} \mathrm{C}$ ) and laboratory $\left(\right.$ at $28^{\circ} \mathrm{C}$ ) conditions was performed on shoots collected from field trips and placed in clean water. In order to monitor pollen tube growth in the pistils, samples were taken 48-54 hours after pollination, fixed in Carnoy's solution (W ojciechowski, 1985) and stained with aniline blue according to Martin (1959). The observations of pollen tubes were made with a fluorescence microscope. Self-incompatibility or cross-compatibility of the cultivars under investigation was evaluated on the basis of the pollen germination index (PGI) according to M a t s u z a w a (1983). The pollination combinations in which PGI was equal to or higher than 2 were regarded as compatible.

Detailed results of the pollen tube observations are presented in the paper by Wojciechowski and Antkowiak (2009).

\section{S-RNase gene analysis}

DNA was purified from young leaves $(1 \mathrm{~g})$ according to the method described by Willi a m s et al. (1990), with modifications. PCR was used to amplify a genomic region of the S-RNase gene containing the HV region. The primers used were designed for annealing at 2 conserved regions of the gene: "FTQQYQ" (TTT ACG CAG CAA TAT CAG) and "IIWPNV" (AC(A/G) TTC GGC CAA ATA ATT) (Ishimizu et al. 1999). The PCR amplification was carried out in the following conditions: $5 \mathrm{~min}$ at $94^{\circ} \mathrm{C}$ for pre-denaturing; 10 cycles of $15 \mathrm{~s}$ at $94^{\circ} \mathrm{C}, 30 \mathrm{~s}$ at $50^{\circ} \mathrm{C}$, and $2 \mathrm{~min}$ at $70^{\circ} \mathrm{C}$; 20 cycles of $15 \mathrm{~s}$ at $94^{\circ} \mathrm{C}, 30 \mathrm{~s}$ at $50^{\circ} \mathrm{C}$, and $2.5 \mathrm{~min}$ at $70^{\circ} \mathrm{C}$; followed by $5 \mathrm{~min}$ at $70^{\circ} \mathrm{C}$. For amplification, $2 \times$ PCR Master MIX (Fermentas, Canada) was used, with the following final concentration of chemicals: Taq DNA polymerase in reaction buffer $(0.25$ unit in $1^{-1}$ of mixture), $\mathrm{MgCl}_{2}(2 \mathrm{mM})$, and dNTP $(0.2 \mathrm{mM})$. Next, the same fragments were cloned and sequenced. For the cloning process, primers were extended by 5'$\mathrm{Sal}$ I restriction site (ACGCGTCGAC). PCR products were digested overnight with $\mathrm{Sal}$ I, and joined to vector pGem 5Zf(+) (Promega, USA). The ligation mix was used for the transformation of $E$. coli TOP10 competent cells (Invitrogen, USA). Twenty clones were chosen for selection by insert PCR amplification and polyacrylamide in $10 \%$ gel electrophoresis. Four clones were selected for sequencing per tree. Sequencing was carried out by means of a DYEnamic ET dye terminator kit MegaBase (GE Healthcare, USA).

In order to identify $\mathrm{S}$ genotypes of all tested cultivars, the particular alleles were identified by comparing the obtained sequences with sequences in the GenBank database using Blast program.

\section{RESULTS}

All the tested $P$. communis cultivars were self-incompatible, and most of them were mutually cross-compatible, both in orchard and laboratory conditions (Table 1). However, in some inter-cultivar crosses full or unilateral incompatibility was observed. Full cross-incompatibility was observed in the following combinations: 'Amfora' $\times$ 'Carola' and 'Carola' $\times$ 'Dicolor', but only under field conditions. In laboratory conditions, at $20^{\circ} \mathrm{C}$ and $28^{\circ} \mathrm{C}$ full cross-compatibility was observed for the cross combination 'Carola' $x$ 'Dicolor' and unilateral cross-compatibility in the case of 'Amfora' $x$ 'Carola'.

Under field conditions, a few cross combinations showed unilateral cross incompatibility. Such cases were observed in the following crosses: 'Radana' $x$ 'Amfora', 'Radana' $\times$ 'Conference', 'Carola' $\times$ 'Conference', 'Conference' $x$ 'Amfora', and 'Conference' $\times$ 'Dicolor'. The reported phenomenon is interesting, because in the laboratory full cross-compatibility was observed in all of these cross combinations.

A unique situation was observed in the cross 'Amfora' $x$ 'Carola', where full cross-incompatibility was observed in the field conditions but unilateral cross-incompatibility in the laboratory conditions.

Generally, in laboratory conditions more cases of cross-compatibility were observed as compared to field conditions. In the laboratory, only the cultivars 'Amfora' and 'Conference'showed unilateral cross-incompatibility, with 'Carola' and 'Red Williams', respectively.

To establish the S-genotypes of the tested cultivars, the HV (hypervariable) regions of the S-RNase genes were amplified, the PCR products ware cloned to the plasmid vector and used for the transformation of E. coli (Fig 1, P. pytater S-alles analysis in $\mathrm{W}$ o $1 \mathrm{k} \mathrm{o}$ et al. 2010). Clones were selected for sequencing on the basis of insert PCR amplification and polyacrylamide in $10 \%$ gel electrophoresis. Selected clones were sequenced and the genotypes were identified by comparing with sequences in the GenBank database using Blast 
program. Sequence alignments demonstrated $100 \%$ homology to the appropriate S-RNase sequences from the database and this enabled undoubted identification of the S-genotypes. The tested cultivars were identified for the following genotypes: 'Conference' - Sd /Sh, 'Red
Williams' - Se/Sl, 'Amfora' - Sd/Sn, (origin 'Conference' $\times$ 'Holenicka'), 'Radana' $-\mathrm{Sd} / \mathrm{Ss}$ (origin 'Louise Bonne of Jersey' $\times$ 'Clapp's Favorite'), 'Dicolor' $-\mathrm{Sd} /$ Se (origin 'Red Williams' $\times$ 'Holenicka'), 'Carola' $\mathrm{Sa} / \mathrm{Sb}$ (origin of 'Johantorp' $\times$ 'Comice') (Table 1).

Table 1

The degree of compliance of self- and cross-pollination in diallel crosses of six pear cultivars (P. communis) based on pollen tube (PT) observations and S-RNase gene analysis

\begin{tabular}{|c|c|c|c|c|c|c|c|c|c|c|c|c|c|}
\hline \multirow[b]{2}{*}{$\begin{array}{l}\text { Paternal } \\
\text { form }\end{array}$} & \multirow{2}{*}{ 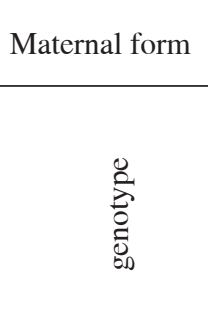 } & \multicolumn{2}{|c|}{ 'Amfora' } & \multicolumn{2}{|c|}{ 'Radana' } & \multicolumn{2}{|c|}{$\begin{array}{c}\text { 'Red } \\
\text { Williams' }\end{array}$} & \multicolumn{2}{|c|}{ 'Carola' } & \multicolumn{2}{|c|}{ 'Konferencja' } & \multicolumn{2}{|c|}{ 'Dicolor' } \\
\hline & & 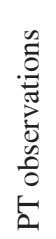 & 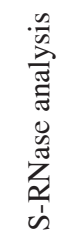 & 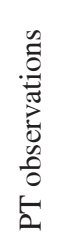 & 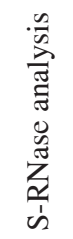 & 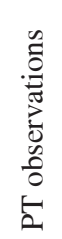 & 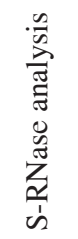 & 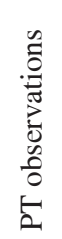 & 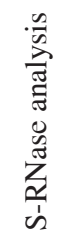 & $\begin{array}{l}0 \\
0 \\
0 \\
0 \\
0 \\
0 \\
0 \\
0 \\
0 \\
0 \\
5\end{array}$ & 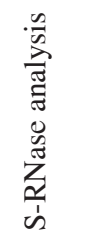 & 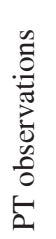 & 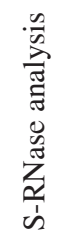 \\
\hline 'Amfora' & $\mathrm{Sd} / \mathrm{Sn}$ & $-*$ & $-* *$ & + & ++ & ++ & +++ & ++ & ++ & - & - & + & ++ \\
\hline 'Radana' & $\mathrm{Sd} / \mathrm{Ss}$ & + & +++ & - & - & ++ & +++ & ++ & +++ & + & +++ & - & - \\
\hline 'Red Williams' & $\mathrm{Se} / \mathrm{S} 1$ & ++ & +++ & ++ & +++ & - & - & ++ & +++ & ++ & +++ & ++ & +++ \\
\hline 'Carola' & $\mathrm{Sa} / \mathrm{Sb}$ & ++ & - & ++ & +++ & ++ & +++ & - & ++ & ++ & - & ++ & +++ \\
\hline 'Conference' & $\mathrm{Sd} / \mathrm{Sh}$ & + & +++ & + & ++ & ++ & +++ & ++ & ++ & + & +++ & + & ++ \\
\hline 'Dicolor' & $\mathrm{Sd} / \mathrm{Se}$ & + & +++ & + & +++ & + & +++ & ++ & ++ & + & +++ & + & +++ \\
\hline
\end{tabular}

*/ Based on PT observations - lack of genetic compatibility; + - partial compatibility; ++ - full compatibility.

**/ Based on S-RNase gene analysis: - lack of cytogenetic compatibility; + - cross compatibility under one environmental condition; ++ - cross compatibility under two environmental conditions; +++ - cross compatibility under three environmental conditions.

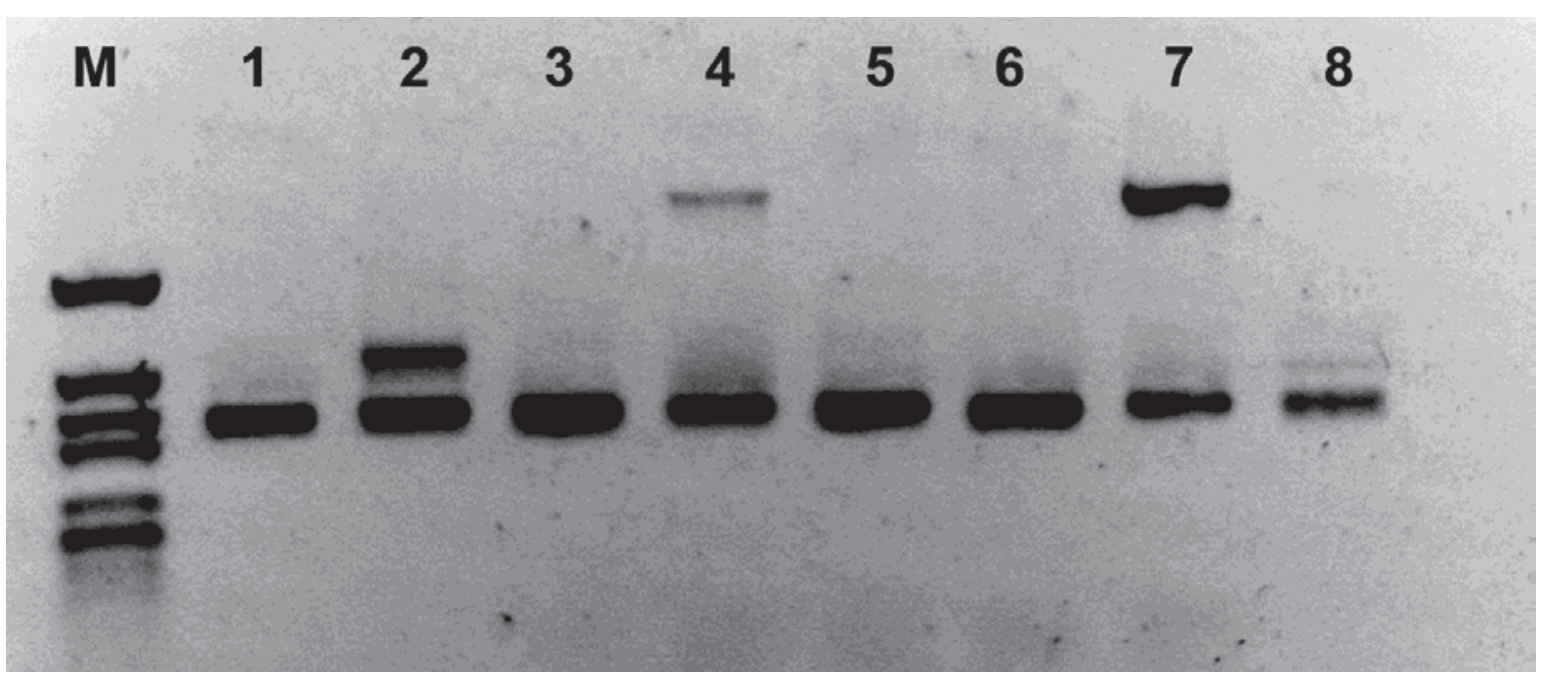

Fig. 1. S-allele PCR products from a reaction performed with the primers FTQQYQ and IIWPNV and DNA extracted from 1,2 two accessions of $P$. pyraster ; 3 - 'Conference'; 4 - 'Red Williams; 5 - 'Amfora'; 6 - 'Radana';7- 'Dicolor'; 8 - 'Carola'. M - size marker pGem5/MspI, fragment size: 765, 489, 404, 339, 220, 190, 147, 110 bp.

\section{DISCUSSION}

The genetic origin of most pear cultivars is not known. Even their true ancestors are often not known. The cultivated pear was created by crossing several wild pear species, and its cultivars are the result of crosses of cultivars, random selection or breeding of random seedlings. For this reason, apart from agronomic assessment, verification and identification of genotypes have become a priority in improving and correcting the handling of collections and the use of 
appropriate cultivars in breeding programs ( $\mathrm{B}$ o t t a et al. 1998).

Knowing the S-alleles has become very desirable in determining the cross-incompatibility between cultivars and may play a very important role in making proper selection of pollinators and parental genotypes in breeding programs as well as in the determination of offspring and the origin of certain cultivars ( $\mathrm{T}$ e $\mathrm{h}$ rani and Lay, 1988; Kester et al. 1994). The determined $\mathrm{S}$ genotypes of the cultivars 'Conference' and 'Red Williams' in our study are consistent with previously published results and the GenBank database ( $\mathrm{H}$ a lá s z and $\mathrm{He}$ ge dú s, 2006; T a k a s a ki et al. 2006). Other cultivars have not been previously examined for signs of self-incompatibility genotype.

Most of the S-RNase sequences of $P$. commus have been characterized (Is himizu et al. 1999; Sanzol and Herrero, 2002; Zuccherelli et al. 2002; Zisovich et al. 2004; Halás z and $\mathrm{He}$ g e d ú s , 2006). The cloning and sequencing of S-RNase fragments described in this paper was aimed at identification of the S-genotypes and at supporting further cytological experiments. Our results confirm the S-genotypes of 'Conference' ( $\mathrm{Sd} / \mathrm{Sh}$ ) and 'Red Williams' (Se/Sl) (S a nzol and Herrero, 2002; $\mathrm{Zu} \mathrm{c} \mathrm{c} \mathrm{here} 11 \mathrm{i}$ et al. 2002), whereas the S-genotypes of 'Amfora' ( $\mathrm{Sd} / \mathrm{Sn}$ ), 'Radana' ( $\mathrm{Sd} / \mathrm{Ss})$, 'Dicolor' ( $\mathrm{Sd} /$ $\mathrm{Se})$, and 'Carola' $(\mathrm{Sa} / \mathrm{Sb}$ ) were supported by the origin of these cultivars.

Most $P$. communis cultivars have been classified as completely or almost completely self-incompatible, although some may be partially compatible, depending on environmental conditions ( $\mathrm{N}$ y é $\mathrm{k}$ i et al. 2000); for this reason, the selection of appropriate pollinators in establishing orchards is extremely important for obtaining good yields. Due to the fact that the pollinator must be cross-compatible with the crop cultivar, the allelic constitution of self-incompatibility of the two crop cultivars must be different, at least in one allele. In the family Rosaceae, the incompatibility locus controls both self-incompatibility and intraspecies cross-incompatibility (De Nettanncourt, 1977). Earlier research on cross-incompatibility has shown that in pear trees it is a rarity. However, in recent studies cases of occurrence of cross-incompatibility are more often described. According to some authors (K e s t e $\mathrm{r}$ et al. 1994; Ege a and B u rg o s, 1996), it may be due to a narrowing genetic base of the newer cultivars, which results from the use of a limited number of parental lines in breeding programs. This is manifested especially in the cultivars 'Williams' and 'Coscia', as the majority of parental lines were created in recent decades (B e ll i n i et al. 2000). This could lead to increased frequency of S-alleles from 'Williams' and 'Coscia' in the new cultivars and consequently increase cross-incompatibility in pear trees. As in the case of
Chinese pear ( $P$. pyrifolia) and other fruit tree species, the problem of incompatibility has been already relatively well identified, but in the case of $P$. communis it is unsatisfactory in this regard ( $\mathrm{L} \mathrm{e} \mathrm{L} \mathrm{e} \mathrm{ze} \mathrm{c} \mathrm{,} \mathrm{1998).}$ The poor progress of the research in this area relating to the pear is often explained by many physiological and environmental factors that may modify the sterility and parthenocarpy. An additional problem with self-incompatibility in the pear lies in the fact that this feature is not so clearly defined, as it is in the case of the cherry, for example, and gradations of self-incompatibility within the cultivars appear to be quite common (Zhang and Hiratsuka, 2000).

According to Hiratsuka et al (2004), the expression of self-incompatibility in a number of plants is variable and depends not only on the physiological condition and flower developmental stage, but also on environmental factors, which was confirmed by the data obtained in our work. The data obtained after selfand cross-pollination under three different temperature conditions show that incompatibility in pear can be affected by the environment, as in some cross-combinations in the field there existed full cross-incompatibility, but in the glasshouse and laboratory full cross-compatibility was observed and vice versa. Moreover, the reaction to environmental conditions was different and there was no regularity in the reaction of particular cultivars. In some combinations after pollination in the field, there was full or unilateral cross-incompatibility. At the same time, in the other two environments tested crossed cultivars were cross-compatible.

The knowledge of pollinators of particular cultivars is based mainly on years of phenological observations and assessment of the degree of pollination depending on the distance between evaluated cultivars. Therefore, pollinator tables included in various manuals and guides are often of only secondary importance. In those tables, information about recommended pollinators for 'Conference' or "'William Pear' and the suitability of these cultivars as pollinators for 'Carola', 'Dicolor' or 'Radana' can be easily found. It is very difficult, and in some cases even impossible, to obtain information about the cultivars 'Amfora', 'Radana', 'Carola', and 'Dicolor'. Therefore, the results obtained by us about the suitability of the above cultivars as pollinators may be useful for orchard practice.

\section{CONCLUSIONS}

1. The results show that six pear (P. communis) cultivars have a distinct genotype which caused different self-incompatibility expression in different environmental conditions.

2. The tested pear cultivars showed complete self-incompatibility. In some inter-cultivar crosses, total or unilateral incompatibility was observed. 
3. The results show that the following are very good pollinators for the studied $P$. communis cultivars:

a) for 'Amfora' - 'Red Williams';

b) for 'Radana' - 'Red Williams', 'Carola';

c) for 'Red Williams' - 'Amfora', 'Radana', 'Carola', 'Conference';

d) for 'Carola' - 'Radana', 'Red Williams ';

e) for 'Conference' - 'Carola'.

4. The following are good pollinators for the studied $P$. communis cultivars:

a) for 'Amfora' - 'Radana', 'Conference', 'Dicolor';

b) for 'Radana' - 'Dicolor';

c) for 'Red Williams' - 'Dicolor';

d) for 'Carola' - 'Amfora', 'Conference', 'Dicolor';

e) for 'Conference' - 'Radana';

f) for 'Dicolor' - 'Amfora', 'Radana', 'Carola', 'Conference', 'Dicolor', 'Red Williams'.

\section{Aknowledgements}

This study was supported in part by the Grant-in-Aid N N310 305034 for scientific research from the Ministry of Education, Poland.

\section{Authors' contributions}

The following declarations about authors' contributions to the research have been madedesigning the experiments: WA, AW; $€ W$, field research: WA, AW; $€ W$ data analyses: WA, AW; ŁW; GŁ comments on the manuscript: WA, AW; ŁW; GŁ; writing the manuscript: WA, AW; ŁW.

\section{REFERENCES}

Bellini E., Sansavini S., Lugli S., Nini S., Rivalta L. 2000. Obiettivi innovatori del miglioramento genetico del pero nel mondo. Riv. Frutt. Ortofloro It. 9: 56-69.

Botta R., Akkak A., Me G., Radicati L., Cas ave c chia V. 1998. Identification of pear cultivars by molecular markers. Acta Hort. 457: 63-70.

De Nettanncourt D. 1977. Incompatibility in Angiosperms. Springer-Verlag (Ed.) Berlin, Germany.

Egea J., Burgos L. 1996. Detecting cross-incompatibility of three North American apricot cultivars and establishing the first incompatibility group in apricot. J. Amer. Soc. Hort. Sci. 121: 1002-1005.

Ha lás z J., Hegedús A. 2006. Self-incompatibility in pears (Pyrus communis L., Pyrus serotina Rehd. and Pyrus ussuriensis). Review. Int. J. Hort. Sci. 12 (2): 87-91.

Hiratsuka S., Hirano A., Kawai Y., Zhang S.L. 2004. Self-incompatibility in Japanese pears: peculiar inhibitory action of S-RNase on self-pollen tube growth in vitro. Acta Hort. 636: 347-356.

Ishimizu T., Inoue K., Shimonaka M., Saito T., Terai O., Norioka S. 1999. PCR-based method for identifying the S-genotypesof Japanese pear cultivars. Theor. Appl. Genet. 91: 691-698. http://dx.doi. org/10.1007/s001220051156

Kester D.E., Gradziel T.M., Micke W.C. 1994. Identifying pollen incompatibility groups in California almond cultivar. J. Amer. Soc. Hort. Sci. 119: 106-109.

Le Lezec M. 1998. Pollinisation du poirer. L'arboriculture Fruitiere, 520: 37-40.

Martin F. 1959. Staining and observing pollen tubes by means of fluorescence. Stain Technology, 34: 125-128.

Matsuzawa Y. 1983. Studies of the interspecific hybridisation in genus Brasssica. II. Crossability in interspecific crosses, B. oleracea $\times$ B. campestris. Japan J. Breed. 33: 321-330.

McClure B.A., Haring V., Ebert P.R., Anderson M.A., Simpson R.J., Sakiyama F., Clarke A.E. 1989. Style self-incompatibility gene products of Nicotiana alata are ribonucleases. Nature, 342: 955-957. http://dx.doi.org/10.1038/342955a0

Nyéki J., Soltész M., Ivancsics J. 2000. Self-fertility of pear varieties conditioned by natural self-pollination (autogamy). Int. J. Hort. Sci. 6: 110-113.

Sanzol J., Herrero M. 2002. Identification of self-incompatibility in pear cultivars (Pyrus communis L.). Euphytica, 128: 325-331. http://dx.doi.org/10.1023/A: 1021213905461

Takasaki T., Moriya Y., Okada K., Yamamoto K., Iwanami H., Bessho H., Nakanishi T. 2006. cDNA cloning of nine $\mathrm{S}$ alleles and establishment of a PCR-RFLP system for genotyping European pear cultivars. Theor. Appl. Genet. 112: 1543-1552. http:// dx.doi.org/10.1007/s00122-006-0257-7

Tehrani G., Lay J.W. 1988. Verification of pedigrees of different sweet cherry cultivars introduced from Vineland through pollen compatibility studies. HortScience, 23: 783-788.

Williams J.G., Kubelik A.R., Livak K.J., Rafalski J.A., Tingey S.V. 1990. DNA polymorphisms amplified by arbitrary primers are useful as genetic markers. Nucleic Acids Res. 18: 6531-6535. http://dx.doi.org/10.1093/nar/18.22.6531

Wojciechowski A., Antkowiak W. 2009. Selection of pollinators for particular pear cultivars (Pyrus comminis L.) based on the observation of the pollen tubes. Herba Pol. 55 (3): 257-265.

Wojciechowski A. 1985. Interspecific hybrids between Brassica campestris and B. oleracea. I. Effectiveness of crossing. Observations of pollen tube growth. The course of embriogenesis. Genet. Pol. 26 (4): 423-436.

Wolko E., Antkowiak W., Sips M., Słomski R. 2010. Self-incompatibility allele in Polish wild pear $(P y$ rus pyrastr (L.) Burgsd.): a preliminary analysis. J. Appl. Genet 51 (1): 33-35. http://dx.doi.org/10.1007/BF0 3195708

Zhang S., Hiratsuka S. 2000. Cultivar and developmental differences in S-protein concentration and self-incompatibility in the Japanese pear. HortScience, 35 (5): 917-920. 
Zisovich A.H., Stern R.A., Shafar S., Goldway M. 2004. Identification of seven S-alleles from the European pear (Pyrus communis L.) and the determination of compatibility among cultivars. J. Hort. Sci. Biotechnol. 79: 101-106.

Zuccherelli S., Tassinari P., Broothaerts W. Tartarini S., Dondini L., Sansavini S. 2002. S-allele characterization in self-incompatible pear (Pyrus communis L.). Sex. Plant Reprod. 15: 153-158. http://dx.doi.org/10.1007/s00497-002-0145-5

Ocena zgodności krzyżowej odmian Pyrus communis L. na podstawie obserwacji lagiewek pyłkowych i analizy genu S-Rnase

\section{Streszczenie}

Krzyżowe zapylenia w układzie diallelicznym pomiędzy odmianami $P$. communis 'Amfora', 'Radana', 'Red Bonkreta Williamsa', 'Carola', 'Konferencja' i 'Dicolor' przeprowadzono w sadzie, a także w warunkach laboratoryjnych $\mathrm{w}$ temperaturach $20^{\circ} \mathrm{C}$ i $28^{\circ} \mathrm{C}$. Na podstawie obserwacji lagiewek pyłkowych oraz po określeniu genotypów S odmian gruszy uprawnej oceniono ich przydatność w charakterze wzajemnych zapylaczy. Otrzymane wyniki wskazują, iż bardzo dobrymi i dobrymi zapylaczami dla badanych odmian $P$. communis są:

\begin{tabular}{cc}
\hline Odmiana & Zapylacze \\
\hline 'Amfora' & $\begin{array}{c}\text { 'Red Bonkreta Williamsa', 'Radana', } \\
\text { 'Konferencja', 'Dicolor' } \\
\text { 'Radana' } \\
\text { 'Red Bonkreta Williamsa', } \\
\text { 'Carola', 'Dicolor' } \\
\text { 'Red Bonkreta } \\
\text { 'Cilliamsa' } \\
\text { 'Amfora', 'Radana', 'Carola', } \\
\text { 'Konferencja', 'Dicolor' } \\
\text { 'Konferencja' } \\
\text { 'Ricolor' } \\
\text { 'Radana', 'Red Bonkreta Williamsa', } \\
\text { 'Konferencja', 'Dicolor' } \\
\text { 'Carola', 'Radana', 'Radana', 'Carola', 'Konferencja', } \\
\text { 'Dicolor', 'Red Bonkreta Williamsa' }\end{array}$ \\
\hline
\end{tabular}

